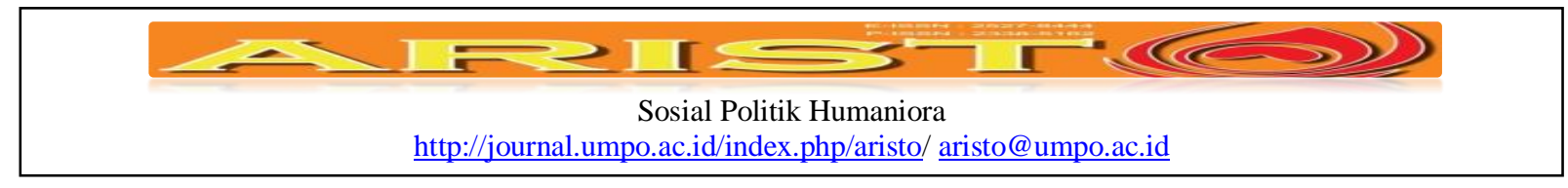

\title{
Pendidikan Konservasi Perspektif Warisan Budaya Untuk Membangun History For Life
}

\author{
Khoirul Huda, Yoga Ardian Feriandi \\ Universitas PGRI Madiun \\ khoirulhuda@unipma.ac.id, yogaardianferiandi@unipma.ac.id
}

\begin{abstract}
This article aims to conduct studies to build character history for life in the younger generation through conservation education of cultural heritage perspective combined with the syntax of contex-learn inquiry. The method used in this article is the lybrary reserach method in which the object studied in this study comes from books, notes, journals, transcripts, research reports and other documents that can be found and related to conservative learning, character, history, etc. the techniques used to collect data with documentation, the researchers identify the discourse of books, papers or articles, magazines, journals, newspapers, web (internet), or other information related to conservative learning, character, history or directly related to the title of writing. after the data collected then the data is analyzed to obtain conclusions, forms in descriptive analysis techniques. The conclusion of this research indicates the importance to immediately apply conservation education in changing mindset and behavior in order to form character history for life especially for the young generation. Given the life of the era of globalization requires a young generation of the future that has three characteristics of knowledge or knowledge society, cultured or cultured society, and civilized or civilized society.
\end{abstract}

\section{Keyword: Conservative Education; Culture; History For Life}

\begin{abstract}
Abstrak
Artikel ini bertujuan untuk melakukan kajian guna membangun karakter history for life pada generasi muda melalui pendidikan konservasi perspektif warisan budaya yang dipadukan dengan sintaks contexlearn inkuiri. Metode yang digunakan dalam artikel ini adalah metode lybrary reserach yang mana objek yang di kaji pada penelitian ini berasal dari buku, catatan, Jurnal, transkrip, laporan penelitian dan dokumen lain yang dapat ditemukan dan terkait dengan pembelajaran konservatif, karakter, sejarah, dll. teknik yang digunakan untuk mengumpulkan data yakni dengan dokumentasi, pada teknik tersebut peneliti mengidentifikasi wacana dari buku-buku, makalah atau artikel, majalah, jurnal, koran, web (internet), ataupun informasi lainnya yang berhubungan dengan pembelajaran konservatif, karakter, sejarah ataupun yang berkaitan secara langsung dengan judul penulisan. setelah data terkumpul maka data tersebut dianalisis untuk mendapatkan konklusi, bentuk-bentuk dalam teknik analisis deskriptif. Kesimpulan dari peneltiian ini menunjukan pentingnya untuk segera menerapan pendidikan konservasi dalam mengubah mindset dan perilaku agar terbentuk karakter history for life khususnya bagi generasi muda. Mengingat kehidupan era globalisasi membutuhkan generasi muda masa depan yang memiliki tiga karakteristik yaitu berilmu atau knowledge society, berbudaya atau cultured society, dan beradab atau civilized society.
\end{abstract}

Kata Kunci : Pendidikan; Konservasi; Budaya; History for life

\begin{tabular}{|ll|}
\hline Submite & $:$ 01 November 2017 \\
Review & $:$ 20 Februari 2018 \\
Accepted & $:$ 30 Juni 2018 \\
Surel Corespondensi & $:$ jovani.audra@gmail.com \\
\hline
\end{tabular}




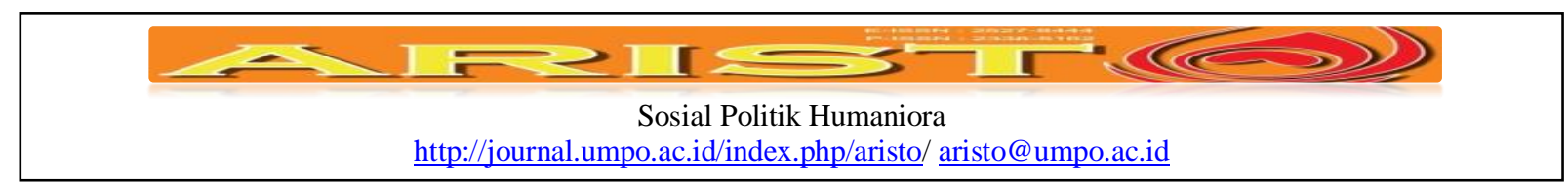

\section{Pendahuluan}

Penguatan budaya pada masa sekarang dianggap salah satu bagian penting untuk pemberdayaan keberlangsungan bangsa masa mendatang. Pemberdayaan yang dalam hal ini merupakan bentuk perlawanan terhadap pengikisan sendi-sendi normatif manusia berbangsa untuk menyelamatkan kekhasan yang dimilikinya dan ingin menunjukkan eksistensi melalui kebermaknaan sejarahnya. Sebagai manusia yang menghargai bangsa, maka jati diri yang dimiliki harus dikuatkan dan diberdayakan. Tidak hanya untuk membedakan tetapi lebih pada menawarkan dan menjaga serta memposisikan nilai-nilai identitas untuk mencapai konstruksi eksistensial. Konstruksi eksistensial dibentuk dari memahami, lalu mentransformasikan simbol identitas atas dasar dominasi diskursus budaya dan historis yang menyertainya. Telaah identitas dalam pusaran dominasi budaya memposisikan manusia dalam tiga kerangka, yaitu (1). tinjauan reproduksi culture, (2). embed culture, (3). elimination culture dan (4). reforma culture. Reproduksi culture dimaknai manusia dalam dinamika sosial baik antar individu bersama kelompoknya melahirkan kebiasaan yang membudaya sehingga dalam konteks ini tercipta hasil silang pembaharuan kebudayaan yang menyertai manusianya. Contoh reproduksi culture dapat dilihat dari adanya penduduk pendatang yang memiliki budaya berbeda dari masyarakat setempat yang kemudian memaksa pendatang untuk melakukan adaptasi agar dirinya diterima oleh lingkungan setempat, dan pada akirnya menciptakan campuran budaya dan menjadi budaya baru misalnya perpaduan budaya daerah dengan Negara Asia/Eropa.

Pada embed culture posisi budaya yang lama mulai mendapat pengaruh dari budaya baru dan pada akirnya mengeser budaya lama yang lebih dulu ada. Contohnya adanya perpaduan motif pakaian asli daerah di Indonesia (batik atau pakaian daerah) dengan pola, motif dan model pakaian yang sedang berkembang saat. Hal itu terjadi karena perkembangan jaman dan era globalisasi yang tidak terbendungkan, sehingga memaksa suatu budaya melekatkan (embed) budaya lain pada dirinya.

Dalam konteks elimination culture, dominasi manusia pada budaya yang telah lama mengikatnya, sedikit demi sedikit mulai luntur. Lunturnya budaya lama tersebut menyebabkan hilangkan simbol-simbol kebudayaan yang selama ini menjadi kekuatannya. Hal tersebut disebabkan meningkatnya perkembangan budaya kontemporer dan dipercaya sebagai pembaharuan yang memiliki nilai positif bagi manusia. Misalnya, ketika zaman dahulu 


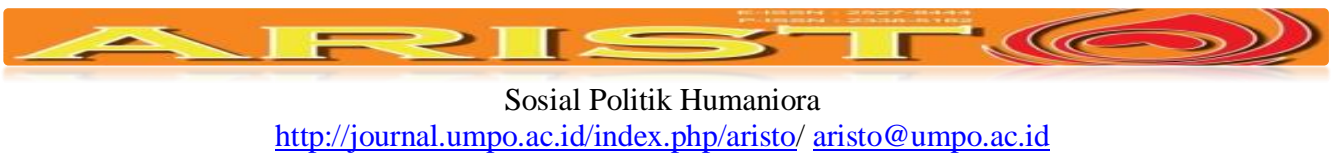

masyarakat bangga untuk mengenakan busana daerah, maka seiring perkembangan zaman akan hilang dengan sendirinya sesuai dengan dan mengikuti mode saat ini.

Hegemoni budaya populer seperti illfitrasi budaya korea mengubah mindset manusia dan memaknai peranan penting dalam perubahan yang lebih modern dengan meninggalkan bekas keaslian warisan budaya yang ada. Anak muda lebih tertarik dengan bahasa dan pakaian korea daripada pakaian khas Indonesia dan bahasa daerah yang ada di Indonesia. Pada akhirnya perubahan tersebut akan mengalami reforma-culture bahwa budaya akan mengalami proses transformasi menjadi baru dan menghilangkan sama sekali kebiasaan (kebudayaan) yang selama ini melekatnya yang sebenarnya mengenai makna, hakikat dan nilai dapat berperan penting dalam kehidupan manusia. Dominasi masyarakat akan terbangun konstruksi identitas kekinian dengan sendi-sendi tatanan sosial-budaya yang dicoba untuk dirubahnya. Dengan demikian, upaya internalisasi terhadap nilai-nilai warisan bangsa perlu diperkuat dengan menempatkan peran campuran budaya secara seimbang baik ranah lokal dan nasional. Merujuk pada warisan budaya, maka pengenalan tersebut untuk mencapai proses internalisasi perlu direncanakan. Tujuannya tak lain adalah agar pergerakan alur dari proses perjalanan warisan budaya tidak tertutup oleh kebijakan dinamika globalisasi yang dapat mempengaruhi, mengabaikan dan bahkan mendiskriminasi budaya setempat yang cenderung terkerdilkan. Pernyataan tersebut sebenarnya menjadi cerminan kita bahwa pengenalan kepada generasi sekarang harus segera mungkin diterapkan. Keterlambatan terhadap prosesnya menyebabkan determinasi budaya akan terhambat. Hakikat pemaknaan nilai-nilai warisan budaya sebenarnya memberikan kontribusi secara nurani untuk selalu menjaga kesadaran dan pengetahuan dan sebagai bentuk mempertahankan dalam menghadapi hegemoni budaya asing agar tidak dihilangkan dan diabaikan. Dengan demikian, persoalan disintegritas budaya tersebut yang merupakan bentuk dari tantangan dan permasalahan yang dihadapi setiap masyarakat bangsa terutama generasi saat ini. Dampak yang dirasakan adalah muncul sikap mereka yang sering memposisikan hasil kebudayaan yang telah diciptakan masa lalu dan justru berpotensi membentuk pengabaian atau kebencian terhadap warisan bangsa. Permasalahannya adalah bagaimana kurangnya menelaah dan membiasakan untuk memahami proses pembentukan kebangsaan melalui bukti-bukti peninggalan hasil budayanya. Kompensasi yang diterimanya adalah menjadikan generasi muda Indonesia ditempatkan dalam posisi underdog mentality. Konsep tersebut dimaknai bahwa menurunnya ruh kecintaan pada bangsa dan meleburnya reforma resistensi budaya baru atau 


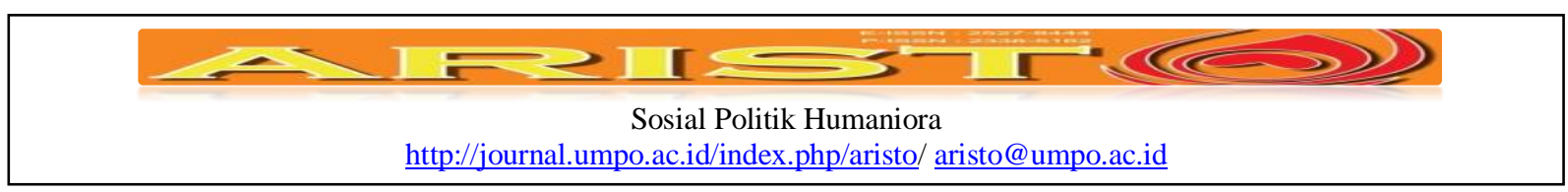

bahkan peniadaan tampilan hasil cipta dan karya kolektivitas bangsanya. Keadaan tersebut menandakan bahwa memperlihatkan ketidak eksisan hasil kebudayaan lokal yang sengaja dilebur dalam budaya populer sehingga terjadi suatu siklus marginalisasi budaya. Keterpurukan tersebut sebagai akibat kurangnya kepekaan dan memaknai terhadap paradigma mata rantai suatu nilai-nilai pembentukan bangsa. Adanya sikap pembiaran dan terperdaya dalam dinamika budaya kekinian. Dalam situasi tertentu, secara laten tahap pemberdayaan warisan budaya belum berjalan dengan baik. Apabila Pewarisan budaya berjalan dengan baik, maka memiliki peran dalam pembangunan identitas. Hal ini disebabkan warisan budaya berhubungan dengan internalisasi identitas. Bilamana cakupan internalisasi tercapai, bukan tidak mungkin kekuatan nasionalisme dan rasa cinta kepada bangsanya bisa diwujudkan. Proses pewarisan tersebut bisa disalurkan pada beberapa kegiatan mendidik berbudaya terutama dalam pembelajaran di keluarga sebagai bagian dari pendidikan informal maupun sekolah yang mengikatkan pada lembaga formal. Mengingat tabiat pendidikan adalah terapan kegiatan pengajaran dengan karakteristiknya untuk memberikan pencerahan informasi serta pengubahan perilaku manusia yang menjadi subyek pendidikan. (Ridhayanti 2017)

Dengan demikian, diperlukan suatu formulasi dalam merancang strategi untuk membangun proses internalisasi serapan national-culture terhadap etnosentrisme globalisasi dalam perspektif integritas subordinasi budaya dalam pangsa multikultural. Salah satunya adalah pendidikan konservasi beridentitas warisan budaya sebagai penyemai dini integritas nasionalisme. Pendidikan konservasi tersebut merupakan salah satu bentuk gagasan dalam mengurangi kondisi disinternalisasi pelekatan kebanggaan pada bangsa dalam kekhasan nasionalismenya. Pada konteks tersebut, pendidikan konservasi yang terpenting adalah menekankan pada upaya penguatan melestarikan warisan budaya dari peradaban bangsa. Heterogenitas peradaban bangsa Indonesia perlu direposisikan dalam segi pemaknaan, simbolisasi, nilai filosofi yang terangkum dalam proses edukasi secara berkelanjutan. Hal itu karena banyak hal dari indonesia yang dapat di gali nilai-nilainya, untuk dijadikan pedoman dalam bertingkah laku (Feriandi, 2017).

Tujuannya tak lain adalah agar dapat membangun karakter history for life pada generasi muda yang ditandai oleh (1). Mempunyai rasa memiliki dan kebanggaan terhadap dinamika perjalanan sejarah bangsa, (2). Peduli terhadap apa yang dimiliki suatu bangsa terutama kecintaan pada kebudayaan lokal sebagai penekan ekspansi budaya luar, (3). Menguatkan 


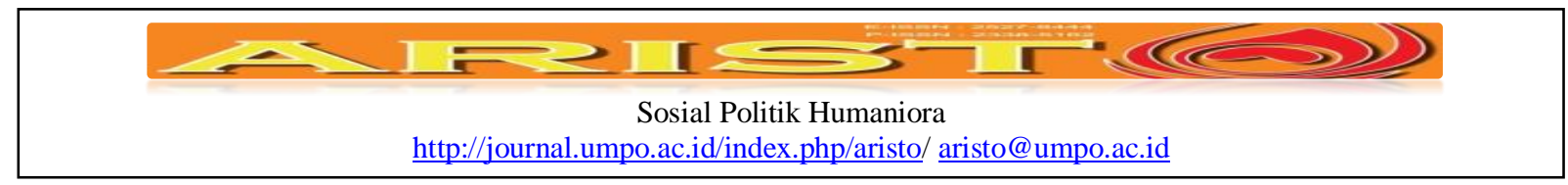

kembali sisi nasionalisme dan cinta tanah air terhadap bangsanya meskipun perkembangan globalisasi terus berekspansi, dan (4). Mampu memberikan pelekatan pengetahuan terhadap pembentukan, perkembangan dan dinamika kebangsaan. Pada dimensi lain, bentuk pendidikan konservasi dalam perspektif warisan budaya merupakan suatu bentuk gerakan pendidikan melalui pembelajaran bermakna yang memfungsikan eksistensi reposisi hasil kebudayaan yang saat ini berada dalam posisi marginal guna mewujudkan kebangkitan bangsa secara berkelanjutan melalui dimensi kultural.

\section{Metode}

Jenis Penelitian yang digunakan dalam penelitian ini yakni penelitian kualitatif, dengan metode deskriptif-kritis. Metode deskriptif krisis merupakan metode yang lebih menekankan pada kekuatan analisis data yang diperoleh melalui berbagai sumber-sumber yang diperoleh dari berbagai buku dan tulisan-tulisan lainnya dengan mengandalkan teori-teori yang ada untuk diinterpretasikan secara jelas dan mendalam untuk menghasilkan tesis dan anti tesis (Abdurrahman \& Soerjono, 1999).

Selain itu pada penelitian ini juga merujuk pada model studi kepustakaan (library research) yang mana objek yang di kaji pada penelitian ini berasal dari buku, catatan, Jurnal, transkrip, laporan penelitian dan dokumen lain yang dapat ditemukan dan terkait dengan pembelajaran konservatif, karakter, sejarah, dll.

Pada penelitian ini teknik yang digunakan untuk mengumpulkan data yakni dengan dokumentasi, pada teknik tersebut peneliti mengidentifikasi wacana dari buku-buku, makalah atau artikel, majalah, jurnal, koran, web (internet), ataupun informasi lainnya yang berhubungan dengan pembelajaran konservatif, karakter, sejarah ataupun yang berkaitan secara langsung dengan judul penulisan, setelah data terkumpul maka data tersebut dianalisis untuk mendapatkan konklusi, bentuk-bentuk dalam teknik analisis deskriptif.

\section{Hasil dan Pembahasan}

\section{Pendidikan Konservasi: Makna Dan Konstelasinya}

Pendidikan konservasi dalam kajian ini tidak akan lepas dari konteks tujuan pelestarian, penyelamatan, pemberdayaan serta pendayagunaan. Makna tersebut secara normatif mengantarkan kepada peserta didik agar memiliki pemahaman pengetahuan dalam 


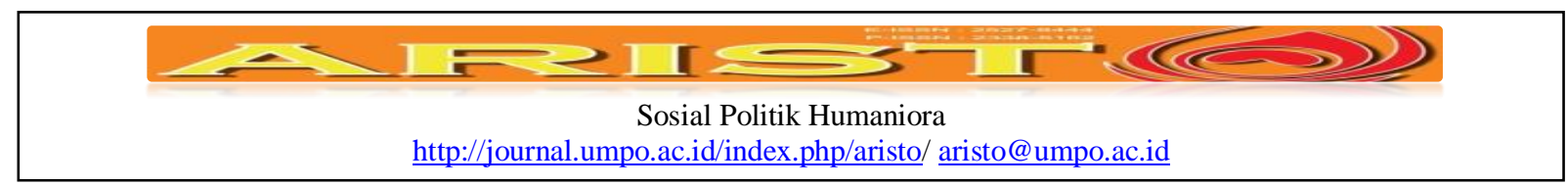

memberdayakan dan menghormati kekhasan untuk eksistensi dan mereposisikannya pada perkembangan dinamika globalisasi sekarang ini. Keterlibatan pendidikan konservasi untuk eksistensi resposisi tersebut karena terdapat konsep pencerahan pengetahuan sehingga muncul kesadaran betapa pentingnya mempertahankan kekhasan yang dimiliki oleh manusia. Mengingat pendidikan merupakan salah satu sarana bentuk pemeliharaan pemahaman pengetahuan dalam mempengaruhi perubahan perilakunya sebagai akibat dari adanya dorongan dari ketercerahan kognitifnya. Keterkaitan dengan pendidikan konservasi ialah bagaimana ketercerahan wawasan berpikir tersebut memberikan dampak dalam pengubahan perilaku dalam menempatkan kembali (mereposisi) subjek yang selama ini belum difungsikan dengan baik yang hakikatnya memiliki nilai dan makna untuk pengembangan keilmuan masa depan. Maka pendidikan konservasi dalam penerapannya mempunyai arti penting dalam mendorong generasi muda untuk menyelamatkan keberagaman nilai-nilai kekhasan dalam kehidupan masyarakat. Pada dasarnya pengertian pendidikan konservasi adalah pendidikan yang mengharapkan adanya perubahan tingkah laku, sikap dan cara berpikir terutama yang berkaitan dengan pengelolaam sumber daya alam da ekosistemnya (Djoko Setiono, 2011. 2).

Sebagaimana yang dimaksud dalam penyataan tersebut adalah dalam sisi normatif titik tekan dalam pendidikan konsevasi terlihat pada pengelolaan perubahan perilaku disertai dengan segala dinamika perkembangan paradigma berpikir yang diwujudkan dalam bentuk sikap untuk dapat memelihara aspek sumber daya alam yang ada dan dimanfaatkan oleh manusia untuk bersanding di kehidupan manusia itu sendiri. Sumber daya alam yang dalam konteks ini sebagai bagian dari pembentuk karakter kepribadian manusia khususnya generasi muda dengan menawarkan pada pengetahuan masa lampau yang memang harus dipelihara dan dilestarikan.

Pada konsep yang lain menjelaskan bahwa pendidikan konservasi merupakan salah satu pembelajaran secara eksperiental dengan memfokuskan pada beberapa hal, yaitu: (1). Untuk mendukung kepedulian dan perhatian terhadap ekonomi, sosial dan keterkaitannya terhadap lingkungan ekologis baik di perkotaan maupun di pedesaan, (2). Untuk menyediakan setiap orang dengan kesempatan untuk mendapatkan pengetahuan, nilai, perilaku, komitmen, kemampuan yang diperlukan untuk menjaga dan meningkatkan kualitas lingkungan hidup, dan (3). Untuk menciptakan pola sikap hidup yang positif baik dari tingkat individu, kelompok dan masyarakat secara keseluruhan terhadap lingkungannya (Alif Sulfiantono, 2012 dalam http://www.tngunungmerapi.org/urgensipendidikan-konservasi/) 


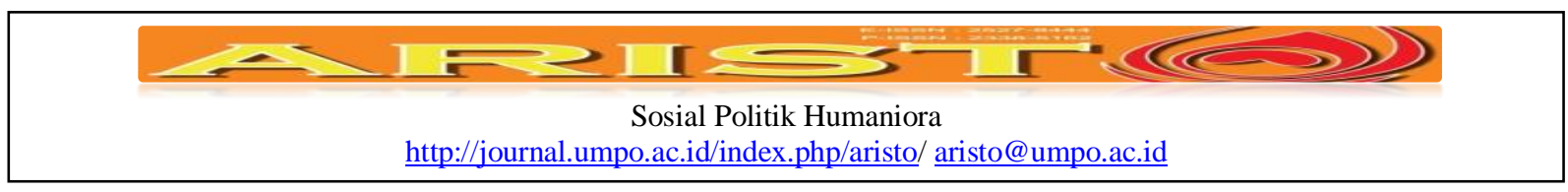

Pernyataan tersebut menitikberatkan pada bagaimana manusia memiliki rasa kepedulian dalam menciptakan bentuk sikap hidup dalam perilakunya sehari-hari yang berkaitan dengan upaya meningkatkan pemeliharaan lingkungan sekitar. Perilaku tersebut juga disertai kemampuan dan pengetahuannya sehingga nilai-nilai subyek konservasinya dapat ditindaklanjuti hingga dimasa depan. Pendidikan yang menekankan pada perubahan perilaku cenderung dimanfaatkan dalam pembelajaran sehingga tercapai wujud peran aktif keterlibatan langsung secara kontekstual tatkala berada dalam tempat atau lingkungan tertentu. Selanjutnya, gerakan konservasi mempunyai misi untuk melakukan pembangunan sumberdaya alam dan berpandangan bahwa manusia menguasai alam dan alam melayani kebutuhan manusia serta dinilai sebagai komoditas untuk keuntungan manusia (Didik Suharjito, 2008).

Sebagaimana dalam pernyataan tersebut bahwa konservasi dipandang sebagai penguatan antara satu sama lain dan saling membutuhkan untuk pembangunan kelangsungan sumber daya alam yang dalam hal ini menempatkan simbolisasi normatif keanekaragaman budaya untuk terus menerus dikuatkan nilai filosofinya dalam memacu generasi saat ini agar tidak punah. Senada dengan, Volare Amanda Wirastari dan Rimadewi Suprihardjo menjelaskan bahwa

Konservasi atau pelestarian adalah salah satu jenis pendekatan dalam perencanaan kota atau penataan ruang yang dalam Perda kota Surabaya No 5 Tahun 2005 menyatakan bahwa pelestarian bangunan dan/atau lingkungan cagar budaya bertujuan untuk mempertahankan keaslian bangunan dan/atau lingkungan cagar budaya, melindungi dan memelihara bangunan atau lingkungan cagar budaya dari kerusakan serta memanfaatkan bangunan atau lingkungan cagar budaya demi kepentingan pembangunan. (Volare Amanda Wirastari dan Rimadewi Suprihardjo, 2012: 63)

Pendapat yang lain dikemukakan Isdaryono bahwa konsep konservasi merupakan proses panjang baik dalam dimensi konservasi material dan non material kemudian membuat sarana prasarana sampai ke masalah aksesbilitas ke lokasi dan mengarah pada pemanfaatan secara ekonomis untuk menunjang nilai-nilai historisnya maupun nilai-nilai emosionalnya yang terkadnung dalam warisan tersebut. Dengan demikian dari beberapa telaah pendapat yang dikemukakan tersebut, maka pendidikan koservasi merupakan suatu tindakan seseorang dalam proses pembelajaran dan mendidik untuk memberikan pengubahan perilaku dan paradigma berpikirnya melalui perubahan tindakan dan sikapnya terhadap lingkungan sekitar yang memiliki unsur-unsur nilai kehidupan dengan harapan terdapat keterjagaan keanekaragaman ekosistem kebudayaannya agar tidak punah, dengan mendorong perilaku kepeduliannya untuk 


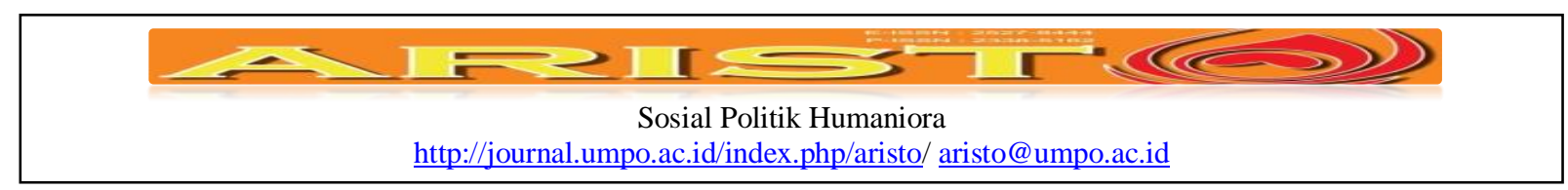

pembangunan kekhasan yang dimiliki masyarakat. (Rikka Agustriana Sinulingga dan Igusti Angung Oka Mahagangga, 2016)

\section{Warisan Budaya Untuk Pendidikan Konservasi}

Secara makna, warisan budaya merupakan wujud peninggalan hasil pemikiran dan karya manusia masa lampau yang secara normatif mengandung nilai-nilai filosofis sebagai bentuk simbolisme dalam pusaran kehidupan masyarakat dahulu kala. Pemaknaan warisan budaya tidak hanya memahami dan mengerti bentuknya secara kronologis, melainkan ada upaya untuk melestarikan, menjaga serta memposisikannya ke dalam penguatan internalisasi di dalam kepribadian setiap manusia khususnya generasi sekarang yang bertujuan agar tindakan punahnya dapat dihindari. Menjaga warisan budaya diperlukan demi kelangsungan kebangsaan yang menekankan pada 1). Wawasan budaya dapat menyadarkan betapa pentingnya mempelajari kronologis sejarah bangsa dari sisi kemegahan budaya, 2). Sebenarnya dalam dimensi masa lampau, bangsa ini memiliki kemegahan yang besar disertai bukti hasil kebudayaannya, dan 3). Hasil karya masa lampau tidak hanya dipandang dalam bentuk visualisasi, melainkan memaknai nilai yang terkandung didalamnya untuk dimanfaatkan dalam proses internalisasi di era sekarang sehingga penguatan sisi pengakuan bisa dirasakan baik secara lokal, nasional dan global. Pengakuan tersebut merupakan sebuah bentuk penghormatan yang bersifat etno-kultural dalam menjaga eksistensi. Warisan budaya secara kategorinya dapat dibagi menjadi dua yaitu warisan budaya bersifat benda dan warisan budaya tak benda. Warisan tak benda dapat dimaknai:

Sebagai praktik, representasi, ekspresi, pengetahuan, dan keterampilan (serta isntrumen, objek, artefak, dan ruang budaya yang terkait dengannya) yang diakui oleh masyarakat, kelompok dan bahkan dalam beberapa kasus, individu sebagai bagian dari warisan budaya mereka. Warisan budaya tak benda ditransmisikan dari generasi ke generasi dan diciptakan berulang-ulang secara terus-menerus oleh komunitas dan kelompok dalam rangka merespons (kebutuhan di) lingkungan mereka, interakasi mereka dengan alam sekitar dan sejarah mereka. Warisan budaya tak benda tersebut memfasilitasi masayarakat dalam rangka membangun identitas dan eksistensi serta mempromosikan penghormatan atas keanekaragaman budaya dan kreatifitas manusia (Hairus Salim, 2014).

Pada prinsipnya warisan tak benda tersebut merupakan hasil kebudayaan dari dimensi

pengetahuan dan merupakan bentuk ekpresi yang dilakuan oleh masyarakat sebagai ungkapan identitasyang menyertainya. Laurajane Smith menjelaskan mengenai karakteristik kriteria sebuah warisan adalah materialitas (wujud kebendaan), usia, estetika, dan/atau sifat monumentalnya yang dipandu dengan penelusuran historis yang luas sehingga dapat diakui sebagai warisan 


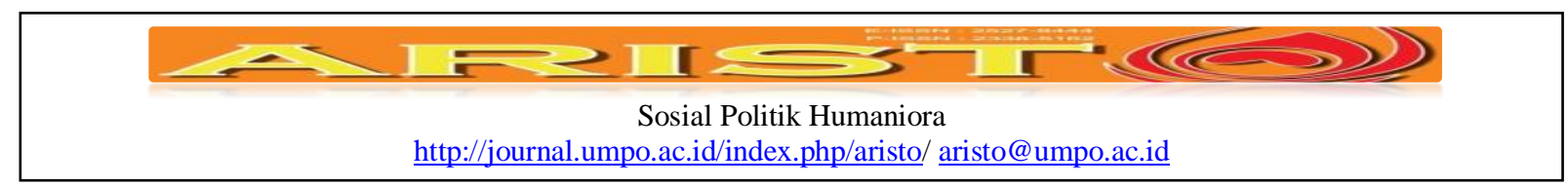

budaya. Warisan budaya bersifat benda adalah wujud materialnya seperti bangunan, situs dan benda cagar budaya yang telah berada pada suatu kawasan dan merupakan aset hasil kebudayaan masa lampau. Keberadaan warisan budaya tersebut penting untuk diperkenalkan ke generasi sekarang guna sebagai bentuk penghormatan, penyadaran dan pengakuan agar warisannya tidak kalah dengan budaya masa kini. (dalam Hairus Salim, 2014)

\section{Model Pendidikan Konservasi Warisan Budaya}

Untuk implementasi pendidikan konservasi diperlukan suatu model dan strategi yang di dalam tahapannya konsisten terhadap upaya membangun pembelajaran yang hierarki pada pendekatan konservatif. Suatu model yang efektif apabila ketercapaian indikator yang termaktub pada ranah tujuan tersebut dapat terlaksana. Pendidik dalam merancang model pendidikan konsetrvasi perlu memikirkan kembali inti pokok capaian pembelajaran yang diinginkan secara spesifik sehingga pada pelaksanaannya memainkan peran penting terutama menyangkut internalisasi nilai-nilai budaya yang beridentitas. Sebagaimana model yang digunakan oleh pendidik pada umumnya, pada prinsipnya model pendidikan konservasi menitikbertakan pada perpaduan teori dengan praktik atau yang biasa disebut dengan pendekatan kontekstual. Pada dasarnya model pembelajaran konservasi merupakan perpaduan dengan pengajaran kontekstual dengnan pendekatan inquiri yang menekankan pada pengalaman belajar, yang kemudian dari pengalaman tersebut peserta didik mampu memaknai kandungan nilai-nilai filosofi dan perkembangannya secara konstruktif. Pada prinsipnya cakupan model mencakup beberapa kegiatan, seperti yang dikemukakan Marquis-Kyle \& Walker dan Alvares (Maman Rachman, 2006) yang meliputi ranah:

a. Preservasi adalah tindakan mempertahankan dengan upaya melestarikan sesuai keadaan asli tanpa ada perubahan dan mencegah penghancuran.

b. Restorasi adalah pengembalian yang telah dibangun disuatu tempat ke kondisi semula yang diketahui dengan menghilangkan atau membangun kembali tambahan atau kompnen semula tanpa menggunakan bahan baru,

c. Rekonstruksi adalah membangun kembali suatu tempat sesuai dengan kondisi semula dan diperbedakan dengan menggunakan bahan baru atau lama,

d. Adaptasi adalah merubah suatu tempat dengan penggunaan yang dapat digabungkan. 


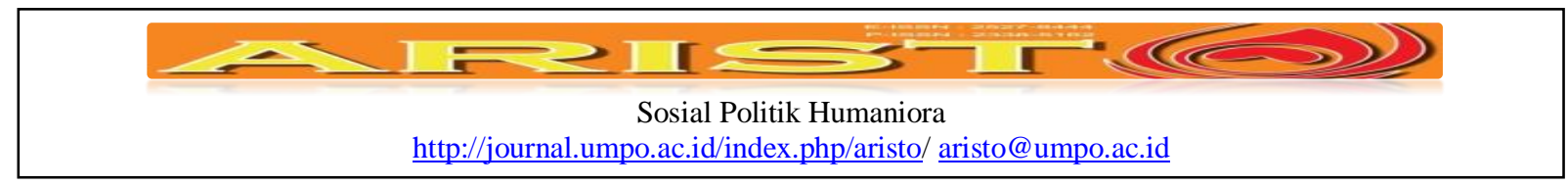

e. Revitalisasi adalah mereposisikan untuk memanfaatkan kembali bangunan yang sudah ada tanpa mengubah dan mengurangi kekhasan yang dimiliki obyek tersebut.

Penjelasan tersebut merupakan rangkaian kegiatan yang bisa dipergunakan dalam upaya pendidikan konservasi secara berkelanjutan. Desain pembelajaran tersebut cukup komprehensift karena setiap ranah memiliki tujuan masing-masing. Pada intinya adalah kerangka tersebut sebenarnya dapat dikombinasi dengan pendekatan inquiry terutama dalam aspek pembelajaran langsung (kontekstual). Sebagaimana yang tercermin dalam pembelajaran kontekstual yang menekankan pada upaya membangun kesadaran terhadap keberadaan warisan budaya agar etnobudaya terbangun. Pada konteks yang lebih luas sebenarnya dapat dilakukan peleburan dengan upaya menggabunkan ke beberapa model pembelajaran yang mempunyai kekhasan kontektual tetapi desainnya masih tetap mengandung dan mencerminkan kegiatan konservatif. Pengembangan model pembelajaran yang telah digabungkan tampak pada gambar berikut ini:

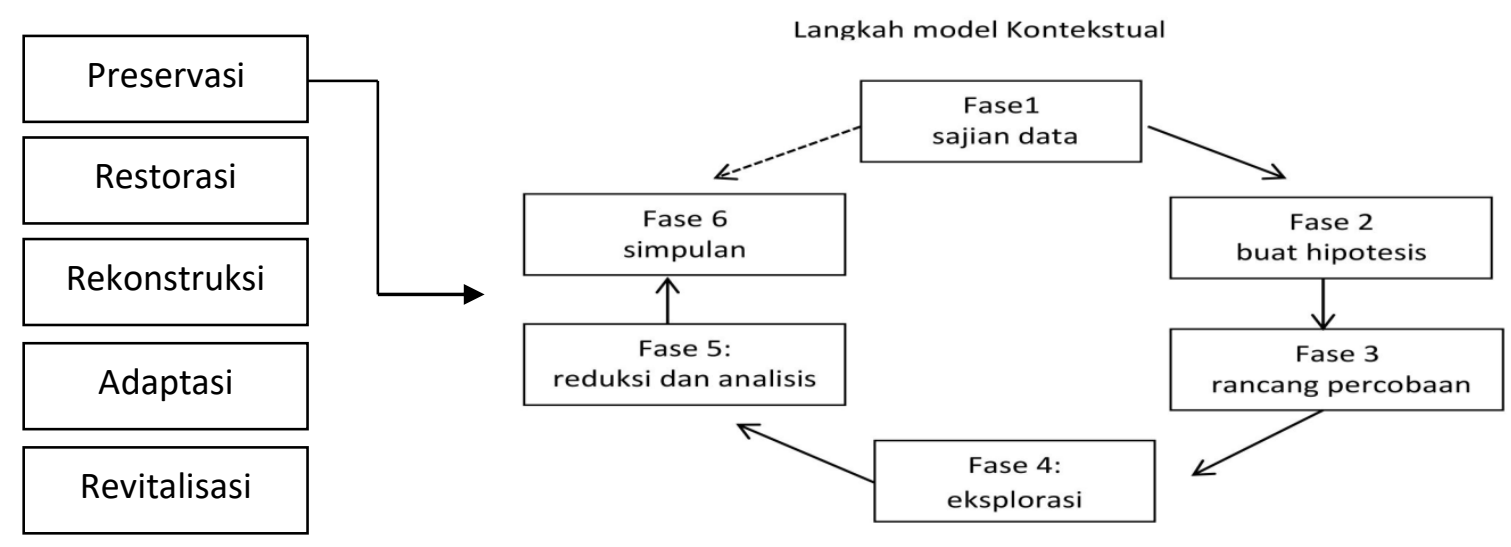

Gambar 1. Model pembelajaran konservasi modifikasi sintaks contex-learn inkuiri Sumber: Trianto (2007)

Gambar tersebut merupakan keterterapan pembelajaran konservasi dengan langkahlangkah yang ditawarkan dalam model kontekstual inquiri yang mana peserta didik berusaha mencari dan mengeksplorasi beberapa warisan budaya dengan arahan dari pendidik. Sehubungan dengan hal tersebut, dalam tulisan ini desain kegiatan yang akan dijadikan bahan rujukan model masih dalam tahap preservasi dimana peserta didik diperkenalkan untuk mengetahui warisan budaya dengan berbagai sumber yang ada baik primer maupun sekunder dan tanpa merubah atau 


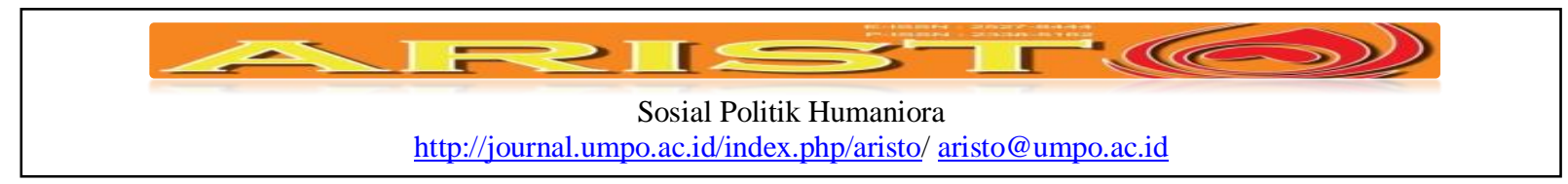

meneliti secara mendalam obyek yang dikaji dan hanya sampai bagian pengamatan dan masih dapat dikembangakan secara berkelanjutan.

\section{Integrasi Pendidikan Konservasi pada mata pelajaran}

Terkait dengan langkah-langkah konstetual seperti di jelaskan di atas maka pada tahapan preobservasi akan meliputi ranah kognitif, afektif dan psikomotorik (Budiyono \& Feriandi, 2017). Pertama kognitif, mengisi otak, mengajarinya dari tidak tahu menjadi tahu, dan pada tahap-tahap berikutnya dapat membudayakan akal pikiran, sehingga dia dapat memfungsi akalnya menjadi kecerdasan intelegensi. Pada tahap ini peserta didik diberikan pengetahuan mengenai pengenalan/disajikan data-data mengenai berbagai macam budaya-budaya atau tempat bersejarah yang ada di Indonesia. Pengenalan tersebut akan lebih optimal jika bisa dilakukan dengan menggunakan strategi pembelajaran "Belajar melalui pengalaman" yakni dengan mengunjungi cagar-cagar budaya secara langsung yang ada di Indonesia. Jika hal tersebut bisa dilakukan maka peserta didik akan mendapatkan pengalaman nyata/Factual yang dapat membantunya untuk memahami nilai-nilai sejarah yang ada, Selain itu dengan mengajak siswa belajar melalui pengalaman maka siswa akan mulai belajar dari hal-hal yang bersifat factual menuju konseptual.

Namun tentu saja mengunjungi cagar budaya secara langsung tidak dapat dilakukan setiap saat, karena keterbatasan dana, waktu dll. Sehingga dalam hal ini pendidik juga dapat mengenalkan sumber-sumber budaya melalui cara lain, misalnya dengan vidio, foto, maupun miniatur dari tempat-tempat bersejarah. Dengan demikian maka pendidik akan lebih menghemat waktu biaya dan tenaga untuk dapat mengenalkan cagar budaya yang ada di Indonesia. Pada tahap ini pendidik menjadi fasilitator bagi peserta didik untuk membandingkan cagar-cagar budaya dalam kondisi ideal yang didapat dari berbagai sumber dan kondisi nyatanya saat ini, diharapkan dengan membandingkanya ranah dari afektif siswa menjadi tergugah untuk dapat membantu melestarikan atau membuat hipotesis dan merancang tindakan untuk mengatasi permasalahan yang ada.

Ranah yang Kedua yakni afektif, yang berkenaan dengan perasaan, emosional, pembentukan sikap di dalam diri pribadi seseorang dengan terbentuknya sikap, simpati, antipati, mencintai, membenci,dan lain sebagainya. Pada ranah ini pendidik berusaha mempengaruhi sisi afektif siswa. Setelah medapat sajian data dan mengetahui berbagai macam permasalahan yang 


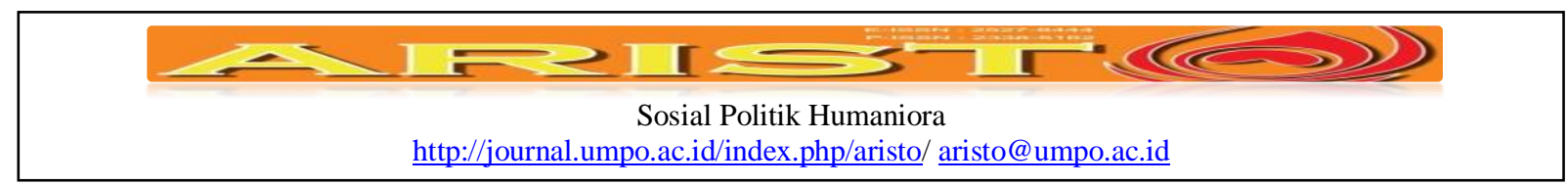

ada maka langkah yang selanjutnya adalah, peserta didik mulai mencari solusi untuk mengatasi masalah tersebut dan membuat hipotesisnya. Untuk itu pendidik dapat menggunakan metode dilema moral yang dihubungkan dengan kebudayaan dan kondisi sejarah yang ada di Indonesia. Dilema moral merupakan suatu kondisi dimana seseorang diperadapkan dengan dua atau lebih kondisi yang tidak mengenakkan, tetapi peserta didik diharuskan harus memilih salah satu kondisi tersebut. Pada hal ini peserta didik diberikan pandanga mengenai suatu dilema yang dihadapi pemerintah untuk merawat dan memelihara tempat-tempat bersejarah. Harapanya adalah peserta didik selain mampu mencari solusi bagi permasalahan yang telah di identifikasikanya, dan tidak sewenang-wenang menyalahkan pihak lain. Dengan metode dilema moral ini ranah afektif peserta didik akan terpengaruhi, sehingga benar-benar berkomitmen untuk melakukan perbaikan atau mengatasi permasalahan yang ditemuinya melalui berbagai macam cara.

Ketiga, psikomotorik, adalah berkenaan dengan action, perbuatan, prilaku, dan seterusnya. Dengan demikian maka peserta didik membuat produk makalah atau karya tulis yang berisi solusi-solusi dari permasalahan yang ada dan ditemuinya ketika melakukan pengamatan. Pada tahap ini peserta didik mulai melakukan ekporasi terkait subyek yang dibuatkan rancangan percobaanya, dan dilanjutkan reduksi dan analisis data serta membuat suatu kesimpulan atas permasalahan yang ada. Dengan demikian ketiga ranah tersebut menjadi bagian yang tidak terpisahkan dari model pembelajaran konservasi modifikasi dengan menggunakan sintaks contex-learn inkuiri. Dari hal itu maka pembelajaran akan mendapatkan hasil yang maksimal karena melalui tahapan yang mengandung dari tiga ranah pengetahuan (Bloem). Selain itu ketiga ranah tersebut juga merupakan cara yang efektif untuk mendidik karakter konservatif peserta didik, hal itu dapat kita lihat dari berbagai kajian tentang karakter. (Budiyono \& Feriandi, 2017).

\section{Kesimpulan}

Pendidikan konservasi dapat diupayakan untuk didesain pada pembelajaran IPS guna memelihara serta menyadarkan peserta didik dalam membangun nasionalisme melalui warisan budaya bangsa. Pembelajaran IPS di anggap sebagai sarana yang tepat membangun History For Life karena "dalam pembelajaran IPS juga terdiri dari berbagai disiplin ilmu sosial dan humanity yang diorganisir dan disajikan secara ilmiah dan psikologis untuk tujuan pendidikan yang berlandaskan Pancasila dan Kebudayaan Indonesia”. Dalam hal ini tidak dapat dimaknai 


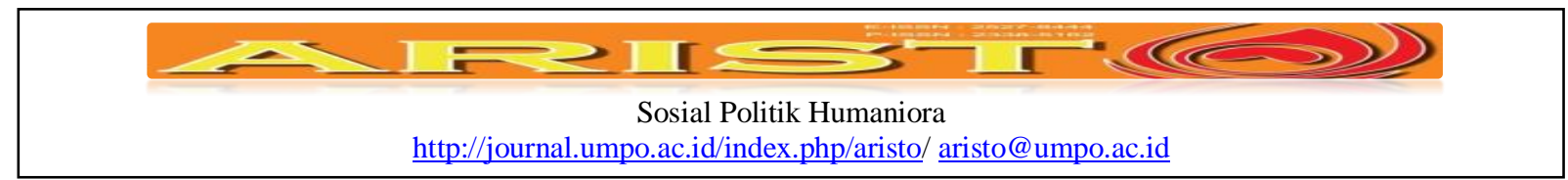

bahwasanya mata pelajaran lain tidak bisa untuk menjadi sarana membangun History For Life, namun dalam konteks ini IPS menjadi mata pelajaran yang secara langsung terkait dengan pengetahuan tentang sejarah. Memperkenalkan sejak dini warisan budaya akan mendorong proses penguatan internalisasi kekhasan budaya bangsa agar tetap eksis di era globalisasi dengan adanya pendidikan konservasi. Mengingat suatu program konservasi sedapat mungkin tidak hanya mempertahankan keasliannya dan perawatannya namun juga tidak mendatangkan nilai ekonomi atau manfaat lain bagi pemilik. Sehingga betapa pentingnya penerapan konservasi dalam mengubah mindset dan perilaku agar terbentuk mentalitas nasionalisme khususnya bagi generasi muda. Mengingat kehidupan era globalisasi membutuhkan generasi muda masa depan yang memiliki tiga karakteristik yaitu berilmu atau knowledge society, berbudaya atau cultured society, dan beradab atau civilized society . 


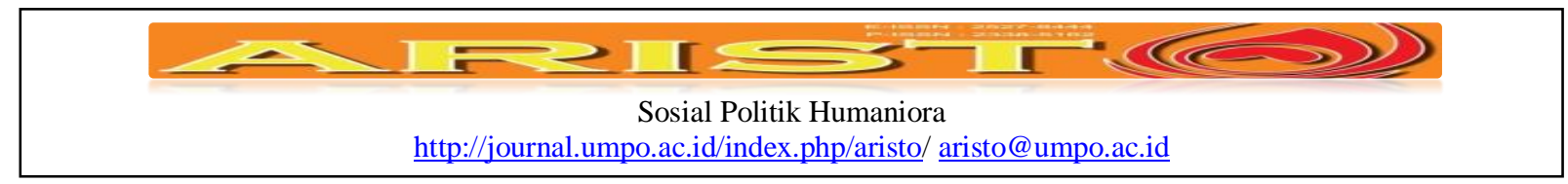

\section{Daftar Pustaka}

Abdurrahman, H., \& Soerjono. (1999). Metode penelitian deskriptif. Jakarta: Rineka Cipta.

Alif Sulfiantono. 2012. Urgensi Pendidikan Konservasi. (Online). dalam http://www.tngunungmerapi.org/urgensi-pendidikan-konservasi/. Diakses 2 April 2017.

Anshori, S. (2016). Kontribusi Ilmu Pengetahuan Sosial dalam Pendidikan Karakter. Edueksos: Jurnal Pendidikan Sosial \& Ekonomi, 3(2).

Budiyono, B., \& Feriandi, Y. A. (2017). Menggali Nilai Nilai Kearifan Lokal Budaya Jawa Sebagai Sumber Pendidikan Karakter. In Prosiding Seminar Nasional Bimbingan dan Konseling, 1,(1), 92-103.

Cucum Herlinawati. 2014. Upaya Unesco Dalam Pelestarian Candi Borobudur Sebagai Situs Warisan Dunia Pasca Erupsi Merapi Tahun 2010. Ejournal Ilmu Hubungan Internasional, 2 (1), 171-182.

Didik Suharjito. 2008. Orientasi Nilai Dan Gerakan Masyarakat Pro-Konservasi Di Indonesia. Media Konservasi, 13(1), 38-45.

Djoko setiono. 2011. Pendidikan konservasi. Dalam pelatihan pendidikan konservasi alam angkatan 26. Makalah disajikan dalam the Indonesian wildlife conservation foundation (IWF) dan Balai Taman Nasional Alas Purwo Banyuwangi, 18-19 Juli 2011.

Feriandi, Y. A. (2017) Revitalisasi moral kewarganegaraan dalam ungkapan Jawa sebagai sumber pembentukan civic culture dan politic culture. JURNAL CIVICS, 14(2), 176-182.

Hairus salim. 2014. Kretek sebagai warisan budaya. Wacana: Jurnal Transformasi Sosial, 34(2), 3-9

Huda, K. (2017). Pengembangan Media Pembelajaran IPS Sejarah melalui Aplikasi Sway Berkonten Indis di SMP Negeri 8 Madiun. Historia: Jurnal Pembelajaran Sejarah dan Sejarah UM Metro, 5(2), 125-142.

Ki Hajar, Dewantara. (2004) Bagian pertama : Pendidikan (Cetakan ketiga) Yogyakarta: Majelis Luhur Persatuan Taman Siswa.

Lickona, T. (1991). Educating for character. New York: Bantam Books.

Maman Rachman. 2012. Konservasi Nilai Dan Warisan Budaya. Indonesian Journal Of Conservation. 1 (1) , 30-39

Marzuki, M., \& Feriandi, Y. A. (2016). Pengaruh Peran Guru Ppkn dan Pola Asuh Orang Tua terhadap Tindakan Moral Siswa. Jurnal Kependidikan: Penelitian Inovasi Pembelajaran, 46(2), 193-206. 


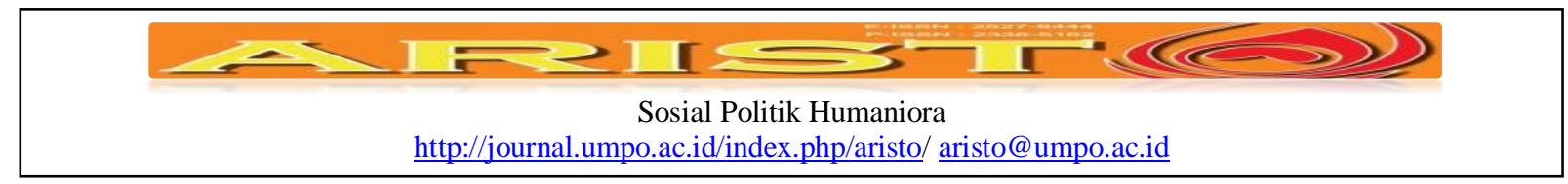

Ridaryanthi, M. Bentuk Budaya Populer Dan Konstruksi Perilaku Konsumen Studi Terhadap Remaja. Jurnal Visi Komunikasi, 13(1), 87-104.

Rikka Agustriana Sinulingga Dan Igusti Angung Oka Mahagangga. 2016. Upaya Konservasi Rumah Adat Karo Dalam Menunjang Pariwisata Budaya Di Desa Lingga Kabupaten Karo Sumatera Utara. Jurnal Destinasi Pariwisata, 4 (2), 139-145.

Raharjo, T. J., Rifai, A., \& Suminar, T. (2015). Keefektivan Manajemen Pendidikan Karakter Pilar Konservasi Budaya melalui Strategi Pembelajaran Inkuiri Sosial bagi Mahasiswa Jurusan Pendidikan Luar Sekolah Fakultas Ilmu Pendidikan Universitas Negeri Semarang. Journal of Nonformal Education, 1(1). 26, 34

Trianto. 2007. Model-model Pembelajaran Inovatif berorientasi kontruktivistik. jakarta: Prestasi Pustaka

Volare Amanda Wirastari Dan Rimadewi Suprihardjo. 2012. Pelestarian Kawasan Cagar Budaya Berbasis Partisipasi Masyarakat (Studi Kasus Kawasan Cagar Budaya Bubutan Surabaya. Jurnal Teknik ITS. 1, (2), 63-67. 